\title{
PERSPECTIVAS BIOÉTICAS EN UN MUNDO EN SINDEMIA
}

\author{
Fernando Lolas Stepke ${ }^{1}$
}

La variedad y calidad de los artículos que los editores de Acta Bioethica examinan y aprueban muestran la vitalidad de la publicación. La autoría se muestra también amplia en lo geográfico.

Es inevitable hacer referencia a lo que ocurre en el mundo en este año de gracia de 2020. Se refleja parcialmente en las contribuciones a este número, especialmente en el artículo relativo a los cambios en la consideración de contratos durante la pandemia de covid-19 y la postura ética derivada de Ricoeur sobre el trabajo en equipo en el campo sanitario. Otros trabajos no aluden directamente a la emergencia porque fueron preparados antes de que ésta empezara a ejercer efectos. Sin embargo, pueden ser leídos en un contexto señalado por la actual situación.

Las propuestas temáticas englobadas bajo el amplio término "bioética" son diversas y los editores deben a veces reflexionar sobre la conveniencia de aceptar para revisión artículos que claramente expanden los límites conceptuales más allá de lo habitual. Parte de los manuscritos rechazados trata temas no pertinentes o desde ángulos que no se ajustan a los lineamientos editoriales. El contexto en que aparece este número de la revista permite reflexiones de algún interés.

La situación mundial en junio de 2020 es única. Le ha tocado a esta generación presenciar y experimentar la mayor crisis social en lo que va del siglo XXI, comparable solamente a las mayores catástrofes del siglo XX como las guerras mundiales o el colapso económico de los años 30, por no hablar de las pandemias, especialmente la de 1918-19.

Es importante destacar que no se trata solo de un agente infeccioso que afecta al cuerpo humano. El modelo de enfermedad que inauguraron los pioneros de la bacteriología es claro: una noxa exterior, el microbio, agrede a un organismo hasta ese momento sano, le provoca enfermedad y necesita ser combatido. En la edad de oro de la bacteriología, aquella en que los investigadores rivalizaban en descubrir nuevos agentes infecciosos o curas para las enfermedades, las disputas se centraban en saber qué determinaba la enfermedad: si el agente externo o el "terreno" del huésped. Hay que recordar las tensiones entre Pasteur y Koch, el escepticismo de Claude Bernard o la negación del papel patógeno por parte de Pettenkoffer, para entender que no estaba solamente en juego la "verdad" científica, sino también la política de la ciencia, las rivalidades nacionales (ciencia francesa versus ciencia alemana) y la necesidad de prioridad. Son tiempos también en que se reactiva la cuestión ética en la obtención de informaciones, incluyendo la ética de qué se considera información. Baste recordar los experimentos de los médicos japoneses que buscaban, infectando prisioneros, ensayar tratamientos y vacunas, o la avidez con que muchas personas enfermas, en las primeras etapas de la investigación sobre el sida, se ofrecieron voluntariamente para la investigación de tratamientos. Ya Neisser había sido censurado por la forma en que estudiaba a personas infectadas.

Un ejemplo de búsqueda de terapéutica óptima lo brinda el caso del salvarsán. Paul Ehrlich, en busca de tratamiento para la sífilis, deseaba encontrar una especie de "bala mágica", que atacara al agente patógeno de manera precisa sin causar daños colaterales en el huésped y sin efectos que durasen más de lo deseable o necesario. Una "therapia sterilisans magna". Ese ideal es difícil de lograr. Todos los agentes curativos tienen efectos fuera del primario, su uso irracional causa resistencias bacterianas y, last but not least, el acceso a los medicamentos encuentra barreras sociales, económicas y geográficas. Piénsese tan solo en la disponibilidad de penicilina, que tan importante papel jugó en la recuperación de sol-

\footnotetext{
${ }^{1}$ Director de Acta Bioethica. Profesor Titular de la Universidad de Chile, Chile Correspondencia: flolas@uchile.cl
} 
dados heridos o en las poblaciones diezmadas por la tuberculosis o la viruela, algunas sin posibilidad de recursos terapéuticos.

Una pandemia como la actual no implica solamente un virus que ataca cuerpos. Significa una alteración del orden social y supone una interacción entre "noxas" . Así, quienes padecen hipertensión arterial, diabetes, tabaquismo o alcoholismo experimentan distinto la enfermedad, cuando ésta se produce. No es menos serio el impacto de los trastornos mentales en la respuesta individual. La angustia y otras patologías determinan aceptar, rechazar o alterar medidas consideradas terapéuticas o preventivas.

Es útil reflexionar sobre esto con ayuda de una perspectiva hermenéutica.

Tras años de proclamar la integridad del ser humano y modelos bio-psico-sociales que suelen ser insatisfactorios, la propuesta del antropólogo Merrill Singer de mediados de los años 90 del siglo XX y reunidas en un libro de 2009, merece examen más allá de su contexto específico. Al hablar de "sindemia" ("syndemics" en inglés) sugiere una interacción entre agentes causales, procesos sociales, estados patológicos, que llevan a una patoplastía compleja. Si hay enfermedades, su presentación es proteica, multiforme. También sus consecuencias. Sindemia puede entenderse como sinergia y epidemia. Pero es mejor tomar la partícula "sin" como indicando fusión de horizontes conceptuales. Que es justamente lo que se precisa, pues la búsqueda apresurada de causas (y a menudo de culpables) obscurece la necesidad de "comprender" qué ocurre y darle nombre adecuado.

Puede parecer innecesario, y hasta ocioso, intentar comprender cuando lo que se necesita es explicar causalmente, pero ambos procesos se necesitan en el largo plazo. Entre otras razones porque solamente en el "gran cuadro" de la comprensión se puede interpretar lo que ocurre, ganar adhesiones y, probablemente, ayudar en los procesos de búsqueda de causas y precisión sobre efectos. Si se observa bien, no siempre hay claridad en qué es causa y qué efecto, y ello explica apresuradas generalizaciones, estigmatizaciones y supuestos "conocimientos" que se diseminan irresponsablemente. El lenguaje de los "determinantes sociales" es un lenguaje estrictamente causal, pero carece de poder explicativo universal. Para saber cómo la pobreza afecta la enfermedad hay que desentrañar muchos "eslabones intermedios". Junto a la racionalidad de las causas, se precisa una racionalidad comprensiva.

Más que describir interacciones, y la literatura médica y antropológica no es escasa en los últimos años, debiéramos considerar el valor de una "perspectiva sindémica" al considerar la actual pandemia y sus consecuencias en los planos social, económico, político, psicológico. Este valor reside, paradójicamente, en abstenerse de culpar o identificar causas y detenerse antes en la comprensión. Lejos de ser ésta una ociosa preocupación llamada despectivamente "filosófica" (aludiendo a que es inútil), permite sentar las bases de algo que siempre cuesta: armonizar discursos, racionalidades, experticias, personas. ¿ $\mathrm{No}_{\mathrm{c}}$ es eso acaso lo que siempre hemos predicado del discurso bioético? Su valor integrador, su estímulo del diálogo, su construcción compartida de acciones posibles.

El horizonte sindémico es el horizonte de la bioética, que, reiteremos, consiste en el uso del diálogo para rotular y resolver problemas y dilemas, en la medida en que estos se pueden definir como relevantes para los seres humanos y su convivencia. 